\title{
Skeletal muscle magnesium and potassium in asthmatics treated with oral beta ${ }_{2}$-agonists
}

\author{
T. Gustafson*, K. Boman*, L. Rosenhall**, T. Sandström+, P.O. Wester++
}

\begin{abstract}
Skeletal muscle magnesium and potassium in asthmatics treated with oral beta ${ }_{2}$-agonists. T. Gustafson, K. Boman, L. Rosenhall, T. Sandström, P.O. Wester. (CERS Journals Ltd 1996.

ABSTRACT: Dietary magnesium has been shown to be important for lung function and bronchial reactivity. Interest in electrolytes in asthma has so far mainly been focused upon serum potassium, especially linked to $\beta_{2}$-agonist treatment. It is known that serum levels of magnesium and potassium may not correctly reflect the intracellular status. We therefore investigated whether asthmatics treated with oral $\beta_{2}$-agonists had low magnesium or potassium in skeletal muscle and serum, and whether withdrawal of the oral $\beta_{2}$-agonists would improve the electrolyte levels.

Magnesium and potassium levels in skeletal muscle biopsies, serum and urine were analysed in $\mathbf{2 0}$ asthmatics before and 2 months after withdrawal of long-term oral $\beta_{2}$-agonists, and for comparison in 10 healthy subjects.

Skeletal muscle magnesium in the asthmatics was lower both before $(3.62 \pm 0.69$ mmol-100 $\mathrm{g}^{-1}($ mean $\left.\pm \mathrm{SD})\right)$ and after $\left(3.43 \pm 0.60 \mathrm{mmol} \cdot 100 \mathrm{~g}^{-1}\right)$ withdrawal of oral $\beta_{2^{-}}$ agonists compared with the controls $\left(4.43 \pm 0.74 \mathrm{mmol} \cdot 100 \mathrm{~g}^{-1}\right)$. Skeletal muscle potassium and serum magnesium did not differ between the groups. Serum potassium was significantly lower both before $\left(4.0 \pm 0.2 \mathrm{mmol} \cdot \mathrm{L}^{-1}\right)$ and after $\left(3.9 \pm 0.2 \mathrm{mmol} \cdot \mathrm{L}^{-1}\right)$ the withdrawal of oral $\beta_{2}$-agonists compared with the control group $\left(4.2 \pm 0.2 \mathrm{mmol} \cdot \mathrm{L}^{-1}\right)$.

The asthmatics had lower skeletal muscle magnesium and lower serum potassium than the healthy controls, both with and without oral $\beta_{2}$-agonists. Whether the findings are related to asthma pathophysiology or treatment is currently being
\end{abstract} investigated.

Eur Respir J., 1996, 9, 237-240.

\author{
*Dept of Internal Medicine, Skellefteå \\ Hospital, Skellefteå, Sweden. **Dept of \\ Pulmonary Medicine and Allergology, \\ Huddinge Hospital, Huddinge, Sweden. \\ Depts of +Pulmonary Medicine and Aller- \\ gology and ++Internal Medicine, University \\ Hospital of Northern Sweden, Umeå, Sweden. \\ Correspondence: T. Gustafson \\ Dept of Internal Medicine \\ Skellefteå Hospital \\ S-93186 Sweden \\ Keywords: \\ Beta-adrenergic receptor agonists \\ bronchial asthma \\ magnesium \\ muscle \\ potassium
}

Received: February 141995

Accepted after revision October 251995

This study was supported by grants from the National Association for Heart and Lung Patients, University of Umeå and Glaxo Sweden AB.
Bronchial asthma is a common disease for which the underlying mechanisms are not fully known. The importance of dietary magnesium for bronchial tonus and airway reactivity has recently been highlighted by BRITTON et al. [1]. Magnesium sulphate is known to cause bronchodilatation in treatment of asthma attacks [2-4]. Magnesium is also essential for normal potassium levels, being a co-factor for sodium-potassium-adenosine triphosphatase(ATPase) in the cell membrane [5]. It is well-known that $\beta_{2}$-agonist treatment can reduce serum potassium $[6,7]$, which has been feared to contribute to arrhythmias in fatal asthma $[8,9]$. The hypokalaemia can be further enhanced by concomitant theophylline treatment [10] and by diuretics [11].

So far, the concern about electrolytes in asthma has been focused on measurements of serum levels. However, it is known that most of the total body potassium and magnesium is intracellular and that deficiency of these ions can exist despite normal contents in serum [12, 13]. Until now, there have been, to the best of our knowledge, no reports on tissue electrolytes in asthmatics. We postulated that oral $\beta_{2}$-agonist treatment in these patients could alter not only serum electrolytes but also tissue electrolytes. Since only diminutive amounts of bronchial tissue may be obtained from asthmatics in vivo, we chose to use skeletal muscle tissue as a model to sample sufficient amounts of human muscle tissue in vivo to assay muscle electrolytes.

The aim of the present study was to investigate whether asthmatics on treatment with oral $\beta_{2}$-agonists had lower potassium and magnesium in skeletal muscle and serum compared with healthy subjects. We also wanted to determine whether cessation of the oral $\beta_{2}$-agonists, in that case, would improve the electrolyte levels in these asthmatics.

\section{Subjects}

Twenty two out-patients with regular controls at the Department of Internal Medicine, Skellefteå County Hospital, who had bronchial asthma diagnosed according to the definition of the American Thoracic Society [14] entered the study. The diagnosis was based upon 
clinical history, forced expiratory volume in one second (FEV1) reversibility of more than $15 \%$, diurnal variability more than $20 \%$ of peak expiratory flow rate (PEFR) or positive methacholine test. Two patients failed to complete and were not evaluated further (denial of further participation and loss of one muscle sample, respectively). Thus, 20 patients completed the study (11 males and 9 females, aged $50 \pm 11$ yrs (mean \pm SD). Their mean duration of asthma was 18.2 \pm 11.4 yrs (mean \pm SD), and their mean FEV1 at the time of the study was $86 \pm 23 \%$ of predicted (mean $\pm \mathrm{SD})$. Twelve patients were nonsmokers and eight were ex-smokers. All patients were treated with inhaled steroids (daily dose $1,245 \pm 490 \mu \mathrm{g}$, mean \pm SD) and inhaled short-acting $\beta_{2}$-agonists. All patients also had $\beta_{2^{-}}$ agonist tablets with prolonged action; terbutaline in 19 patients and salbutamol in 1. One patient had $7.5 \mathrm{mg}$ once daily, and the other 19 patients $5-8 \mathrm{mg}$ twice daily. All patients were clinically stable and there were no obstacles for withdrawal of the oral $\beta_{2}$-agonists. Four patients had nebulizing therapy with $\beta_{2}$-agonist and nine patients had theophylline tablets. Exclusion criteria were treatment with oral steroids, diuretics or potassium sparing agents.

Ten healthy subjects, mainly hospital staff, asymptomatic and with normal lung function (FEV1 114 $\pm 12 \%$ pred) served as a control group (5 males and 5 females, aged $48 \pm 9$ yrs). Two control subjects were smokers.

\section{Methods}

Following a prestudy visit the patients returned for Visit 1, when skeletal muscle biopsy, blood and $24 \mathrm{~h}$ urine samples were collected and FEV1 and vital capacity (VC) were measured. Oral $\beta_{2}$-agonists were then withdrawn, whilst the other asthma medications were unchanged. After 2 months, the same investigations were performed at Visit 2. PEFR and the use of inhaled $\beta_{2}$ agonists were recorded during 1 week before and after Visit 1 and during the week before Visit 2. A short course of oral steroids was allowed during the study if deterioration occurred. In the healthy control subjects, skeletal muscle biopsies, blood and $24 \mathrm{~h}$ urine samples were taken on a single occasion.

Muscle biopsies were performed by a percutaneous needle technique developed by Bergström [15]. All specimens were taken from the lateral portion of the quadriceps femoris muscle, $15-20 \mathrm{~cm}$ proximal to the knee. The muscle tissue (in our study weighing 4.1-41.4 $\mathrm{mg}$, mean $14.9 \mathrm{mg}$ ) was placed on a piece of quartz glass and with nonmetal tweezers carefully dissected free from all visible fat and connective tissue. All traces of blood were wiped off by rolling the specimens on the piece of quartz glass. The muscle tissue was then placed on a platinum hook and dried in an oven at $110^{\circ} \mathrm{C}$ to constant weight, extracted in $1 \mathrm{~mL}$ of petroleum ether for $2 \mathrm{~h}$ and dried to constant weight again, and the fatfree dry solids (FFDS) weight was calculated. The electrolytes were extracted from the muscle tissue by treatment with $250 \mu \mathrm{L} 2.5 \mathrm{M} \mathrm{HNO}_{3}$ for $24 \mathrm{~h}$. From each sample, $100 \mu \mathrm{L}$ of the supernatant was diluted to $10 \mathrm{~mL}$ with
$0.25 \% \mathrm{SrCl}_{2}$ and analysis for $\mathrm{Mg}$ and $\mathrm{K}$ in the tissue was performed on an Atomic Absorption Spectrophotometer (Varian 1275). The results were calculated in mmol. $100 \mathrm{~g}^{-1}$ FFDS. For a proper quality control of the measurements, a certified reference material was used (IAEA animal muscle (H-2) from International Atomic Energy Agency, Vienna, Austria).

Serum and urine concentrations of potassium were analysed by conventional autoanalyser technique and of magnesium by atomic absorption. Reference values were the following: serum potassium $3.6-4.5 \mathrm{mmol} \cdot \mathrm{L}^{-1}$; serum magnesium $0.7-1.0 \mathrm{mmol} \cdot \mathrm{L}^{-1}$; urine potassium 50-100 mmol.24 $\mathrm{h}^{-1}$; and urine magnesium 2.5-7.5 $\mathrm{mmol} \cdot 24 \mathrm{~h}^{-1}$.

The study was blinded for the technicians who analysed the serum and skeletal muscle samples. The study was approved by the Local Committee of Ethics. The participants were informed in writing and their consent was obtained orally.

\section{Statistics}

Student's t-test for paired observations (Statview®, Abacus Concepts for Macintosh $($ ) was used for comparison of the serum, muscle and urine values in the asthmatics and for comparison of FEV1 at the beginning and at the end of the study. Unpaired t-test was used for analysis of the differences in electrolyte concentrations between the asthmatics and the healthy subjects. Wilcoxon signed rank test was used for comparison of consumption of $\beta$-agonists as needed at the beginning and at the end of the study. Calculations were made with 95 percent confidence intervals $(95 \% \mathrm{CI})$ and a p-value of 0.05 or less was regarded as statistically significant.

\section{Results}

Two patients deteriorated and required a short course of oral steroids, during week three and seven, respectively, after withdrawal of oral $\beta_{2}$-agonists. The other patients were clinically stable throughout the study. FEV1 before and after the withdrawal of oral $\beta_{2}$-agonists was (mean \pm SD) $78 \pm 28 \%$ and $81 \pm 25 \%$ pred, respectively, a difference which was not statistically significant. The dosages per day of inhaled aerosol or powder of $\beta_{2}$-agonist were significantly fewer $(\mathrm{p}<0.05)$ during the week before withdrawal of oral $\beta_{2}$-agonists (median 5.4; 5 th-95th percentiles 0.0-14.4) compared with the last week of the study (median 6.3; 5th-95th percentiles 0.0-16.9). The usage of nebulized salbutamol/terbutaline was unchanged between these two weeks for the four patients who had nebulizers at home. Due to missing data, urine magnesium was analysed in 19 samples before stopping oral $\beta_{2^{-}}$ agonists, in 20 after stopping, and in 8 healthy subjects. For urine potassium the numbers were 14, 20 and 9, respectively.

Skeletal muscle magnesium (table 1) was significantly lower in the asthmatics, both before and after the termination of oral $\beta_{2}$-agonists, compared with the control 
Table 1. - Magnesium and potassium in skeletel muscle, serum and urine of asthmatics $(n=10)$ before and 2 months after termination of oral $\beta_{2}$-agonists compared with healthy subjects $(n=10)$

\begin{tabular}{|c|c|c|c|}
\hline & \multicolumn{2}{|c|}{ Asthmatics } & \multirow[t]{2}{*}{ Healthy subjects } \\
\hline & Before & After & \\
\hline Muscle-Mg mmol.100 $\mathrm{g}^{-1}$ FFDS & $3.62 \pm 0.69 * *$ & $3.43 \pm 0.60 * * *$ & $4.43 \pm 0.74 * *, * * *$ \\
\hline Muscle-K & $37.83 \pm 5.06$ & $36.14 \pm 4.17$ & $34.19 \pm 5.87$ \\
\hline Serum-Mg $\mathrm{mmol} \cdot \mathrm{L}^{-1}$ & $0.93 \pm 0.10$ & $0.92 \pm 0.09$ & $0.89 \pm 0.06$ \\
\hline Serum-K & $4.0 \pm 0.2^{*, \circ \circ}$ & $3.9 \pm 0.2 * *, \circ \circ$ & $4.2 \pm 0.2 *, * *$ \\
\hline Urine-Mg mmol.24 $\mathrm{h}^{-1}$ & $5.2 \pm 2.4$ & $5.7 \pm 2.7$ & $6.5 \pm 3.5$ \\
\hline Urine-K & $71 \pm 23$ & $65 \pm 22$ & $64 \pm 38$ \\
\hline
\end{tabular}

Values are presented as mean \pm SD. Asthmatics $v s$ healthy subjects: $*$ : $\mathrm{p}<0.05 ; * *: \mathrm{p}<0.01 ; * * *: \mathrm{p}<0.001$. Asthmatics before $v s$ after termination or oral $\beta_{2}$-agonists. ${ }^{\circ}: \mathrm{p}<0.01$. FFDS: fat-free dry solids.

group $(\mathrm{p}<0.01$ and $\mathrm{p}<0.001$, respectively: mean differences -0.82 and $-1.00 ; 95 \%$ CI -1.38 to -0.26 and -1.52 to -0.49$)$. The differences remained significant $(\mathrm{p}<0.05$ before and $\mathrm{p}<0.001$ after the termination of oral $\beta_{2^{-}}$ agonists) even when omitting the four patients who had nebulizing $\beta_{2}$-agonist therapy and the two patients who needed oral short course steroids. Skeletal muscle potassium did not differ significantly between asthmatics and healthy controls.

Serum potassium (table 1) was significantly lower in the asthmatics both before $(\mathrm{p}<0.05$; mean difference $0.2 ; 95 \% \mathrm{CI}-0.4$ to 0 ) and after the withdrawal of oral $\beta_{2}$-agonists ( $\mathrm{p}<0.01$; mean difference $-0.3 ; 95 \% \mathrm{CI}-0.5$ to $-0.1)$ compared with the control group. It was also reduced after the withdrawal $(\mathrm{p}<0.01$; mean difference $0.1 ; 95 \%$ CI 0 to 0.2 ).

Serum and urinary magnesium and urinary potassium did not differ significantly between the groups (table 1).

\section{Discussion}

The low tissue magnesium in asthmatics is a novel finding. In a recent epidemiological report by BRITTON et al. [1] it was concluded that higher magnesium intake was related to higher FEV1 and reduced bronchial reactivity. This suggests that magnesium levels may have clinical importance in asthma and is in accordance with the finding of skeletal muscle magnesium deficiency in our material of moderate to severe asthmatic subjects which raises concern about disturbance of the cell membrane stability [5]. In contrast, DE VALK et al. [16] recently reported equal magnesium content in blood cells of asthmatics and controls; however, the correlation of magnesium in blood and tissues has been shown to be poor [17, 18], hence their results do not necessarily contradict the present ones.

A possibility that needs to be considered is that the oral $\beta_{2}$-agonist treatment may have caused the low muscle magnesium. If so, it was unexpected that the level was not normalized 2 months after cessation of oral $\beta_{2}$ agonists. Beta $a_{2}$-agonists can reduce serum magnesium through urinary loss or intracellular shift [19], but we did not find increased excretion of magnesium in urine.
Interest in magnesium levels in asthma dates back to the first half of this century, when low serum magnesium levels were shown in some asthmatics, who were successfully treated with magnesium sulphate [20]. Magnesium acts as a calcium antagonist and affects smooth muscle tone $[20,21]$. In recent years, there has been evidence that hypomagnesaemia can contribute to increased bronchial reactivity $[1,22]$, which in turn can be reduced by inhaled magnesium sulphate $[23,24]$. Several studies have shown a bronchodilating effect by intravenous magnesium sulphate in asthma deterioration [2-4] and it has been proposed as an adjunctive treatment in patients with poor response to $\beta_{2}$-agonists. In a study on the bronchodilating effect of intravenous magnesium sulphate in six patients with acute severe asthma [4], both serum levels and intracellular concentrations (erythrocytes) of magnesium were within normal limits. An investigation in chronic obstructive pulmonary disease (COPD) patients admitted to the Intensive Care Unit [25] showed low muscle magnesium values in $15(47 \%)$ of 32 patients but no alteration of serum magnesium levels. Serum magnesium falls in response to high catecholamine levels, for example in acute myocardial infarction, and it has also been shown to fall in patients receiving infused but not inhaled $\beta_{2}$-agonists [19].

In contrast to the differences described in the level of skeletal muscle magnesium, the potassium level in skeletal muscle was not different in asthmatics compared with controls, which contrasts with the findings of FIACCADORI et al. [25], who found lower muscle and intracellular potassium in patients with COPD admitted to the Intensive Care Unit.

Potassium in serum, on the other hand, was significantly lower in the asthmatics compared with the control group, and it fell significantly after withdrawal of oral $\beta_{2}$-agonists. The reason for these findings is unclear. Previous studies have not demonstrated prolonged depression of serum potassium by $\beta_{2}$-agonists $[26,27]$.

Skeletal muscle potassium in the asthmatics and in the control group was slightly lower compared with earlier studies on healthy subjects. WIDMAN [28] and SJÖGREN [29] reported mean values of 43.70 and $46.40 \mathrm{mmol} \cdot 100 \mathrm{~g}^{-1}$ FFDS, respectively. This may be due to differences in the atomic absorption method used. However, it does 
not affect the outcome of the results in this study, since we included a parallel healthy control group for comparison.

In conclusion, we found low tissue magnesium in asthmatics compared with the healthy subjects. Whether this is related to the pathophysiology of asthma or a pharmacological effect is currently under investigation.

\section{References}

1. Britton J, Pavord I, Richards K, et al. Dietary magnesium, lung function, wheezing and airway hyperreactivity in a random adult population sample. Lancet 1994; 344: $357-362$.

2. Okayama H, Aikawa T, Okayama M, Sasaki H, Mue S, Takishima T. Bronchodilating effect of intravenous magnesium sulfate in bronchial asthma. J Am Med Assoc 1987; 257: 1076-1078.

3. Skobeloff E, Spivey WH, McNamara RM, Greenspoon L. Intravenous magnesium sulfate for the treatment of acute asthma in the emergency department. J Am Med Assoc 1989; 262: 1210-1213.

4. Noppen M, Vanmaele L, Impens N, Schandevyl W. Bronchodilating effect of intravenous magnesium sulfate in acute severe bronchial asthma. Chest 1990; 97: 373-376.

5. Skou JC. The influence of some cations on an adenosine triphosphatase from peripheral nerves. Biochim Biophys Acta 1957; 23: 394-401.

6. Gelmont DM, Balmes JR, Yee A. Hypokalemia induced by inhaled bronchodilators. Chest 1988; 94: 763-766.

7. Crane J, Burgess C, Beasley R. Cardiovascular and hypokalaemic effects of inhaled salbutamol, fenoterol and isoprenaline. Thorax 1989; 44: 136-140.

8. $\quad$ Benatar SR. Fatal asthma. N Engl J Med 1986; 314: 423-429.

9. Mitchell EA. Is current treatment increasing asthma mortality and morbidity? Thorax 1989; 44: 81-84.

10. Whyte KF, Reid C, Addis GJ, Whitesmith R, Reid JL. Salbutamol-induced hypokalaemia: the effect of theophylline alone and in combination with adrenaline. $\mathrm{Br}$ J Clin Pharmacol 1988; 25: 571-578.

11. Struthers AD, Whitesmith R, Reid JL. Prior thiazide diuretic treatment increases adrenaline-induced hypokalaemia. Lancet 1983; i: 1358-1361.

12. Dyckner T, Wester PO. The relation between extra- and intracellular electrolytes in patients with hypokalemia and/ or diuretic treatment. Acta Med Scand 1978; 204: 269-282.

13. Wester PO. Magnesium. Am J Clin Nutr 1987; 45: 1305-1312.

14. American Thoracic Society. Standards for the diagnosis and care of patients with chronic obstructive pulmonary disease (COPD) and asthma. Am Rev Respir Dis 1987; 136: 225-244.
15. Bergström J. Muscle electrolytes in man determined by neutron activation analysis on needle biopsy specimens: a study on normal subjects, kidney patients and patients with chronic diarrhoea. Scand J Clin Lab Invest 1962; (Suppl.) 68: 1-110.

16. de Valk HW, Kok PTM, Struyvenberg A, et al. Extracellular and intracellular magnesium concentrations in asthmatic patients. Eur Respir J 1993; 6: 1122-1125.

17. Ralston, MA, Murnane MR, Kelley RE, Altshuld RA, Unveferth DV, Leier CV. Magnesium content of serum, circulating mononuclear cells, skeletal muscle and myocardium in congestive heart failure. Circulation 1989; 80: 573-580.

18. Dyckner T, Wester PO. Skeletal muscle magnesium and potassium determinations: correlation with lymphocyte contents of magnesium and potassium. J Am Coll Nutr 1985; 4: 619-625.

19. Haffner CA, Kendall MJ. Metabolic effects of $\beta_{2}$ agonists. J Clin Pharm Ther 1992; 17: 155-164.

20. Mathew R, Altura BM. The role of magnesium in lung diseases: asthma, allergy and pulmonary hypertension. Magnes Trace Elem 1991-1992; 10: 220-228.

21. Levine B, Coburn J. Magnesium, the mimic/antagonist of calcium. N Engl J Med 1984; 310: 1253-1255.

22. Rolla G, Bucca C. Hypomagnesemia and bronchial hyperreactivity: a case report. Allergy 1989; 44: 519521.

23. Rolla G, Bucca C, Bugiani M, Arossa W, Spinaci S. Reduction of histamine-induced bronchoconstriction by magnesium in asthmatic subjects. Allergy 1987; 42: 186-188.

24. Rolla G, Bucca C, Arossa W, Buigani M. Magnesium attenuates methacholine-induced bronchoconstriction in asthmatics. Magnesium 1987; 6: 201-204.

25. Fiaccadori E, Del Canale S, Coffrini E, et al. Muscle and serum magnesium in pulmonary intensive care unit patients. Crit Care Med 1988; 16: 751-760.

26. Bengtsson B, Fagerström PO. Extrapulmonary effects of terbutaline during prolonged administration. Clin Pharmacol Ther 1982; 31: 726-732.

27. Scheidegger K, O'Connel M, Robbins D, Danforth E. Effects of chronic $\beta$-receptor stimulation on sympathetic nervous system activity, energy expenditure, and thyroid hormones. J Clin Endocrinol Metab 1984; 58: 895-903.

28. Widman L. Skeletal muscle potassium and magnesium in diuretic treated patients: effects of potassium-sparing diuretics or magnesium supplementation (Dissertation). University of Umeå, Sweden, 1988.

29. Sjögren A, Florén CH, Nilsson A. Magnesium and potassium status in healthy subjects as assessed by analysis of magnesium and potassium in skeletal muscle biopsies and magnesium in mononuclear cells. Magnesium 1987; 6: 91-99. 